\title{
MAKING SENSE OF SIMMONS: UNDERSTANDING AND USING SIMMONS MARKET DATA AND OTHER MARKETING DATABASES
}

\author{
Kara Gust Rawlins, Michigan State University, gustk@msu.edu
}

\begin{abstract}
For business students and faculty, especially those engaged in marketing decisions, it is crucial that they have an understanding of the essential marketing tools and information systems available to them. This paper will feature the methodology and use of one of these tools, Simmons Choices3, and its integration into a graduate level marketing research course at Michigan State University. It will provide a background of the Simmons National Consumer Study and highlight the collaboration between a marketing faculty member and a business librarian in presenting the Simmons Choices3 program to marketing students and teaching them how to make marketing decisions from its data.
\end{abstract}

Keywords: Simmons, Choices3, Marketing data, Marketing Information Systems, Library Databases, National Consumer Study, Collaboration

\section{INTRODUCTION}

With marketing data at a premium and corporations facing tough economic times trying to reach their target market with as much reduced costs as possible, it is essential that today's marketing students understand the marketing information systems and databases available to them. There is a wealth of resources available for making marketing decisions used in both businesses and universities today. Unfortunately many business students lack the knowledge of these resources and essential data tools. There is seemingly so much information provided on the Internet, that students are not prepared for conducting and mining marketing research using subscription databases. It is essential that business librarians and faculty collaborate to teach these resources and tools to students, especially those in marketing. One of these tools, Simmons Choices3, is an essential component of the course Marketing 806 offered in the Eli Broad College of Business at Michigan State University. This class has an extensive assignment integrating the use of Simmons National Consumer Study marketing data through the Choices 3 software application. This course is taught every spring semester with one class session taught by a business librarian on how to use the Choices 3 program and interpret the data.

This paper will provide a background of the Simmons National Consumer Study - its history, use, and methodology. It will highlight the collaboration between the marketing business faculty member and a business librarian in presenting the Simmons Choices3 program to MBA students enrolled in Marketing 806. It will also explore the wealth of other marketing information sources available to both business and universities such as Mintel, IBIS World, and MarketLine.

\section{RELATED LITERATURE}

It has been well documented over the last several years that business students are lacking in information-seeking skills and are not being adequately prepared by business schools to be information savvy. Kanter [7] stresses the importance of the concept of the "knowledge company," where "information has become the leading business asset." He furthers that successful companies "are those that can turn data (raw materials) into information (finished goods) and then into knowledge (meaningful action based on the information)" [7]. It is the information literate business student that will be able to turn data into knowledge for true business success.

There have been numerous ways explored and suggested in the literature for business students to become information literature, with the appropriate information-mining skills. Senoir, et al. [9] provide an excellent study of business students and their perceptions and use of the library, revisiting a study performed 30 years ago. They detail how multiple studies show that business students have the consistent perception that "free Web resources are easier to use than library resources" [9]. Thus, they suggest successful collaboration models include course-specific integration, extensive in-class instruction with library content embedded within WebCT/Blackboard course pages, and co-teaching relationships [9]. Less prevalent in the literature is how library instruction and information-seeking skills 
are provided to graduate students. Cooney and Hiris [1] establish a model for librarian collaboration with business faculty to provide a successful semesterlong integration of information literacy into a graduate finance course. They emphasize the importance of establishing a framework with the business faculty member from syllabus creation to final assessment of the course.

The information-seeking skills of marketing students are even more necessary as firms today are striving to predict consumer behavior rather than just tracking it [10]. Also, as firms face hard economic times, they are looking for ways to harvest specific marketing data more quickly and efficiently, with skillful workers proficient in marketing databases. As Teer, et al. state, "firms now have so much information that it is often very costly to glean the specific data that can be used to devise meaningful strategies...many mangers just do not have an understanding of what to do with the terabytes of data collected" [10]. It is imperative for firms today to place an emphasis on analyzing to data to identify the most profitable customers for the most strategic advantage [2]. Teer, et al. continue to emphasize the need for specific database marketing courses, stressing that "students should become acquainted with the most frequently employed marketing decision-making tools to grasp how new techniques, specifically data mining and modeling, are used in the design and implementation of today's marketing programs" [10]. This is especially true from businesspeople and practitioners who indicate that they were less-well prepared in using marketing databases, even though they rated highly the importance of using them in a marketing context [3]. It is clear from the literature that marketing students need to be equipped with appropriate information-seeking behaviors along with data retrieval and analysis skills, including those of one of the most prevalent marketing information provides, Simmons Market Research Bureau.

\section{SIMMONS NATIONAL CONSUMER STUDY}

Simmons Market Research Bureau, now Experian Simmons, a wholly-owned subsidiary of Experian Marketing Solutions, is recognized worldwide as the leading organization for providing consumer behavior data. Known as "The Voice of the American Consumer ${ }^{\mathrm{TM}}$ for over 50 years, Experian Simmons was founded by legendary market researcher Willard R. Simmons, "a pioneer in the use of audience measurement studies to better understand consumer attitudes and behavior and more effectively target marketing and advertising campaigns" [4].

Volume X, No. 2, 2009

\section{History}

Since the 1950s, Simmons Market Research Bureau has been providing companies with consumer behavior data through numerous ongoing behavioral studies and surveys. Since 1960, it has conducted the National Consumer Study (NCS), its flagship product first known as The Study of Media and Markets. The National Consumer Study is the first syndicated national consumer survey launched in the United States [5]. The NCS annually surveys 25,000 U.S. individuals 18 years of age and older as well as households across multiple categories including indepth demographics, psychographics, lifestyles, attitudes, opinions, and product usage behavior. It includes coverage of all major media, 450+ product categories and $8,000+$ brands. It also provides projections to national U.S. adult population with extensive attention to quality control. The great power and strength in the NCS is its multiple data variables that can be manipulated using the Simmons Choices 3 software. Its data provides companies and researchers alike with extensive consumer behavior patterns that can be tracked and analyzed over time.

\section{Methodology \& Measurement}

The Experian Simmons National Consumer Study uses a "patented, multi-frame sample design...to produce representative measures of consumer behavior and attitudes to products, brands and media." It surveys American adultsHispanics/Latinos and non-Hispanics, both Englishspeaking and Spanish-speaking [6].

The Experian Simmons National Consumer Study consists of a two-phase data collection period; households are contacted by telephone to obtain permission to participate, and then survey booklets are mailed to eligible household members. The survey is self-administered, self-paced, and can take as many as five hours to complete.

All respondents are asked the same questions, regardless of race, age, etc. Clients may also obtain more detailed Hispanic information by subscribing to the Simmons National Hispanic Consumer Study, which asks "an additional set of "Hispanic only" questions of Hispanic respondents. These additional data variables include extended demographic, lifestyle and psychographic information for Hispanic respondents and they are made available to Experian Simmons National Hispanic Study subscribers with the appropriate data license" [6]. 


\section{SIMMONS CHOICES3}

Simmons NCS data can be manipulated through a special program purchased through Simmons called Choices3-a software program with an ample learning curve as shown in Figure 1.

Users can create cross-tabulations of demographics, psychographics, product usage data, and media habits by setting up a table. To do this, users must follow these steps:

1) Select the survey they want-population or household, and year

2) Select the demographic criteria from the list of questions and add it to the rows

3) Select the product data criteria from the list of questions and add it to the columns

4) Run analysis and view results in the Choices3 viewer

\section{Sample Search}

To demonstrate the data that can be generated using Choices3, the following is a sample search a marketing team might need to answer in trying to analyze their competition or find their target market (see Table 1). The sample search used data from the NCS Fall 2005 individual population survey, using the following variables to generate the cross-tab.

\section{Interpreting the Results}

Figure 2 provides a cross-tabulation of NCS data in Choices3, showing owners of Sprint cell phones by age group.

When looking at the cross-tabulation generated by Choices3, the data and numbers can be overwhelming, especially to students who have never been previously introduced to such analysis. To help break down the analysis, the key numbers to look at are sample size and index (see Table 2). Projected (000) numbers are a good indicator as well.

Based upon the data given in Figure 2, it is clear that the target market for Sprint cell phones would be ages 18-24 and 25-49. The sample size is well over 50 , more than an adequate sample so as not to skew the data. The index number is well over 120 , indicative that cell phone owners ages 18-24 are 2549 are much more prevalent users of this brand over the rest of the population. This data can be extremely powerful to the decision makers when determining product campaigns and analyzing the competition.
The great power of Choices 3 is in its manipulationtables can be created from any number of criteria, cross-tabulated, combined, and viewed over time to indicate trends. Table 3 presents a question a marketing team might ask to determine their competitors.

Figure 3 shows the cross-tab generated from running the search in Table 3. From the numbers, it is clear that among 18-24 and 25-24 year olds, Sprint's closest competitor is LG; among 35-49 year olds, possibly Blackberry but the sample size is only 37 so more likely LG and Motorola; and among those over 50 years old, Verizon.

\section{SIMMONS AT MICHIGAN STATE UNIVERSITY GAST BUSINESS LIBRARY}

Simmons Choices 3 has been a long-standing tool at the Gast Business Library, used widely by advertising, marketing, retailing, and hospitality students. Due to its expensive licensing, it is available only on eight computers in the Business Library. It is not available via the Internet or remotely. Current data is also not available to academic institutions - it must be at least three years old.

\section{MSC 806: Marketing Analysis}

For the past two years, the business librarian liaison to the marketing department has worked closely with a marketing professor to provide instruction on using Simmons to the Marketing 806 class - a graduate level marketing class open only to MBA students. This class covers essential the analysis of data gathered from a variety of sources such as online marketing databases, statistical analysis software, sales forecasting, data mining techniques, scanner data and analysis, and Web site traffic metrics and analysis. Vital to the course is an extensive marketing data assignment using Simmons Choices3 software. The assignment consists of the students creating a complete profile of the users of a product sub-category or brand of their choice. This profile consists of answering such questions as what are the demographics, opinions, lifestyles, reading habits, other product usage and buying habits of the subcategory's or brand's users. The assignment also consists of an analysis of the managerial implications of the data they find. They must answer the question of how the data and information provided in their profile could be used in developing a marketing strategy for their future firm. 


\section{Library Instruction Session on Simmons}

For the past two years, Spring 2008 and 2009, the business librarian has provided Simmons instruction in the Gast Business Library for one session of the MSC 806 class-lasting about two hours. The session is provided in a computer lab in the Business Library, however, the computers do not have Choices 3 on them (due to limited licenses because of its high cost) so there is no hands-on instruction possible. To best facilitate the session, the librarian demonstrated setting up a search using Choices3 through a variety of examples using PowerPoint. Sample searches specifically addressed the students' assignment which consisted of their finding specific consumer product usage and demographic characteristics. Examples are provided in Table 4.

The business librarian began the session by demonstrating how the students must first prepare and plan their search before using Choices3. Because it does not present a "Google-like" search where freetext can be entered, it presents challenges to users. They must first carefully plan their approach and ask themselves questions before they begin such as shown in Table 5.

Next, the librarian selected data from the Choices3 program and demonstrated how to combine it to create a cross-tab. The librarian addressed the importance of keeping searches simple-if too complex, it becomes more confusing. In addition, combining multiple variables causes the sample size to become too small and unreliable. After each search example, analysis from the librarian and marketing professor followed, with questions from the students on how to interpret the data.

To supplement the library instruction session, the librarian offered one-on-one training on Simmons via appointment and supplies a basic guide to using Choices3 (both online and in print format).

\section{Results}

Overall, the projects in the past two years have been successful and students have gained an appreciation and understanding for the importance of Simmons data. One problem, however, is that the students struggle at first finding a product-sub-category or brand with appropriate sample sizes. They also have some difficulty getting started using the correct survey and selecting which variables to create their cross-tab. They display the most uncertainty in first analyzing what they want to know about their

Volume X, No. 2, 2009 product sub-category or brand. It is recommended that a more hands-on training be provided through either small group sessions or by somehow licensing Simmons Choices 3 for the entire Business Library computer lab so 28 students can access it at the same time. It would also be extremely helpful to offer two sessions on Simmons during the semester, rather than just one.

\section{OTHER MARKETING DATABASES AND RESOURCES}

The Simmons National Consumer Study offers highquality marketing data that is a fundamental resource in the corporate marketing world. It is good to evaluate, however, whether there are equivalent alternatives to the NCS. It is also good to note other marketing databases that can help supplement Simmons data with analysis from other reputable analysts and data sources. The following are a few marketing databases that offer excellent insight into markets and consumers.

\section{MRI}

The closest competitor to Simmons would be Mediamark Research \& Intelligence (MRI) with a long-standing reputation for providing consumer demographic, psychographic, product and media usage - all very similar to Simmons. Similar to Simmons, their flagship product, The Survey of the American Consumer, collects information on adult consumers - their demographics, product usage, media choices, lifestyles, and attitudes. It measures "usage of nearly 6,000 product and service brands across 550 categories... along with the readership of hundreds of magazines and newspapers, Internet usage, TV viewership to the program level, national and local radio listening, Yellow Pages usage and Out-of-Home exposure" [8]. The vast difference between MRI and Simmons is in its data collection. Instead of mailing out the survey, each year, MRI conducts face-to-face interviews in the homes of each survey respondent $-26,000$ in total. A more in-depth study is required to fully analyze the data in MRI versus Simmons.

\section{Mintel (Mintel International Group Ltd.)}

Mintel is a highly-reputable marketing analysis company providing consumer and marketing data to both corporations and libraries. It began as a UK company in 1972, providing food and drink research for the UK. Today it operates in Australia, China, Japan, the United States, as well as the UK. It

Issues in Information Systems 
provides extensive market coverage, especially competitor and consumer analysis. Demonstrating the reputation, reach, and breadth of Simmons NCS, Mintel uses Simmons data extensively throughout their reports. Reports average 100 pages in length and incorporate both tables and text to help corporate decision-makers how to best reach their target market and analyze their competition. Its strength over Simmons is that it provides both numbers and textual analysis which helps the unsophisticated user. However, the data cannot be manipulated specifically with cross-tabulations as in Simmons. It is, however, a wonderful compliment to Simmons and should be used in conjunction with it.

\section{IBISWorld}

Another leader in the world of market analysts is IBISWorld, offering analysis on over 700 U.S. industries and 50 global industries. Established over 35 years ago, IBISWorld has been producing extensive market research reports for both corporate and academic institutions. Its reports average 40 pages in length and contain a wealth of both textual analysis and data to help decision-makers determine the status of their markets and competition. The substantial differences among IBISWorld and Mintel and Simmons is the emphasis on market segment data, industry conditions, market share and competitor details, versus the emphasis on specific consumer product usage and media habits.

\section{MarketLine}

MarketLine is another leader in providing marketing and industry data. Its parent company, Datamonitor, has a long history of providing reliable information on current industry trends and market research. Through MarketLine, users can access smaller yet worthwhile data on market segmentation, market share, industry size and competition, and industry trends over time. It does not, however, provide access to Simmons data and marketing information that can be manipulated. Also, it does not provide consumer demographic and product usage details nearly as much as Simmons and Mintel.

\section{Comparisons of Marketing Databases}

The advantages to using Mintel, IBISWorld, and MarketLine over Simmons in the academic setting is the timeliness of the data. Mintel, IBISWorld, and MarketLine all update their reports annually or even more often and make this available to academic institutions as well as corporate subscribers. Usually in an academic situation, having older data is not a problem as most professors are simply using Simmons as a learning tool, without needing current data for decision-making. However, this does limit faculty in their own research and students in their interest of using Simmons as well. Many students are disappointed when they cannot research the recent and trendier products in Simmons Choices3.

\section{CONCLUSIONS}

To succeed in the business world today, it is imperative to teach and equip marketing students (especially graduate students) with marketing data research skills. For them to thrive and provide appropriate data for crucial marketing decisions in their future firms, they need to be instructed in various marketing databases and analysis tools available to them. At Michigan State University, the relationship between a marketing faculty member and business librarian has been established to accomplish this through an extensive Simmons data assignment, however more needs to be done. Being able to provide hands-on instruction is fundamental for retaining skills - this is something that is being addressed by the business librarian for future classes. Providing additional small group hands-on instruction sessions is also something the business librarian can do to improve upon students' understanding of Simmons and other marketing data. Moreover, business schools and marketing departments need to establish semester courses in collaboration with the business library for marketing data research and methods. This will work to provide students with the essential marketing research skills that will be required of them in their future positions.

\section{REFERENCES}

1. Cooney, M. \& Hiris, L., Integrating Information Literacy and Its Assessment into a Graduate Business Course: A Collaborative Framework. Research Strategies, 2003. 19: p. 213-232.

2. Davenport, T.H., Competing on Analytics. Harvard Business Review, 2006. 84(1): p. 110.

3. Davis, R., Misra, S., \&Van Auken, S., A Gap Analysis Approach to Marketing Curriculum Assessment: A Study of Skills and Knowledge. Journal of Marketing Education, 2002. 24: p. 218-224.

4. Experian Simmons. Company History. 2009, Available from: 
http://www.smrb.com/web/guest/history-ofexperian-simmons [accessed 2009 June 23].

5. Experian Simmons. National Consumer Study. 2009, Available from: http://www.smrb.com/web/guest/coresolutions/national-consumer-study [accessed 2009 June 23].

6. Experian Simmons. The National Consumer Study Methodology. 2009, Available from: http://www.smrb.com/web/guest/experiansimmons-methodology [accessed 2009 June 24].

7. Kanter, J., Ten Hot Information Technology (It) Issues and What Makes Them Hot. Information Strategy: The Executive's Journal, 2003. 19: p. 23.

8. Mediamark Research \& Intelligence. The Survey of the American Consumer. 2009,
Available from: http://www.mediamark.com/showcontent.as px? content $=\sim /$ The Survey of the America n_Consumer/000 The Survey of the Ame rican Consumer.xhtml [accessed 2009 July 1].

9. Senior, H., Wu, K., Martin, D.M., \&Mellinger, M., Three Times a Study: Business Students and the Library. Journal of Business \& Finance Librarianship, 2009. 14(3): p. 202-229.

10. Teer, H.B., Teer, F.P., \&Kruck, S.E., A Study of the Database Marketing Course in Aacsb Accredited Business Schools. Journal Of Marketing Education, 2007. 29(3): p. 245-253.

Figure 1. Choices3

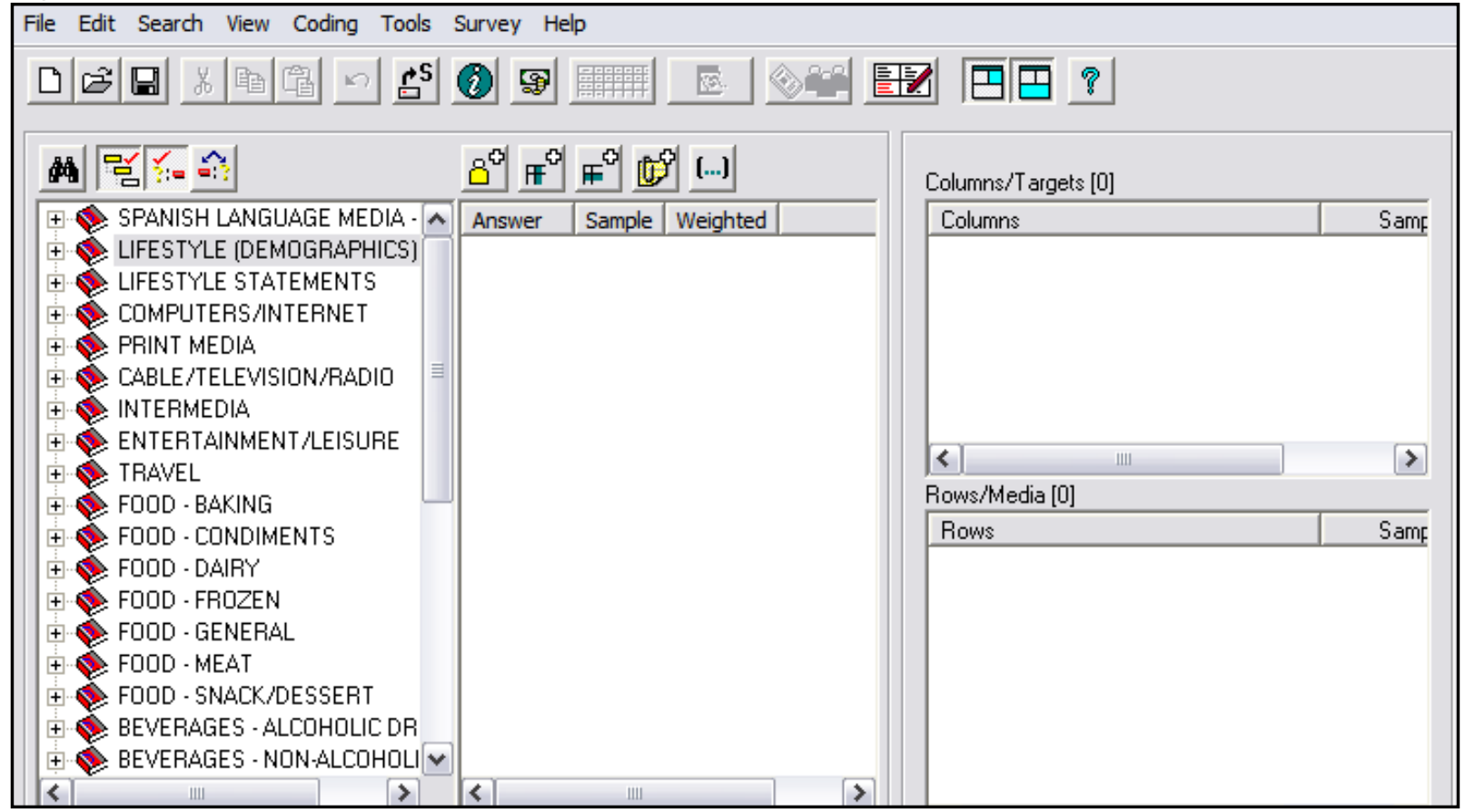

Table 1. Sample Question 1

\begin{tabular}{|l|l|l|}
\hline QUESTION & DEMOGRAPHIC VARIABLE & PRODUCT VARIABLE \\
\hline $\begin{array}{l}\text { Which age groups own } \\
\text { Sprint cell phones? }\end{array}$ & Age (Ranges 18-24, 25-34, 35-49, 50+) & Cell phone brand: Sprint \\
\hline
\end{tabular}


Figure 2. Owners of Sprint Cellular Phones by Age Group

\begin{tabular}{|c|c|c|c|}
\hline & elements & total & $\begin{array}{l}\text { CELLULAR/ } \\
\text { WIRELESS } \\
\text { PHONES: } \\
\text { CELLULAR/ } \\
\text { WIRELESS } \\
\text { PHONES - } \\
\text { BRANDS } \\
\text { OWNED: }\end{array}$ \\
\hline total & $\begin{array}{r}\text { Sample } \\
(000) \\
\text { vert } \% \\
\text { horz } \% \\
\text { Index } \\
\text { Base }\end{array}$ & $\begin{array}{r}24,617 \\
211,425 \\
100 \% \\
100 \% \\
100 \\
100 \%\end{array}$ & $\begin{array}{r}1,072 \\
7,829 \\
100 \% \\
3.70 \% \\
100 \\
3.70 \%\end{array}$ \\
\hline $\begin{array}{l}\text { DEMOGRAPHIC } \\
\text { S (PERSONAL } \\
\text { INFORMATION): } \\
\text { AGE: } 18-24\end{array}$ & $\begin{array}{r}\text { Sample } \\
(000) \\
\text { vert\% } \\
\text { horz } \% \\
\text { Index } \\
\text { Base }\end{array}$ & $\begin{array}{r}2,417 \\
23,866 \\
11.3 \% \\
100 \% \\
100 \\
11.3 \%\end{array}$ & $\begin{array}{r}142 \\
1,428 \\
18.2 \% \\
5.98 \% \\
162 \\
.68 \%\end{array}$ \\
\hline $\begin{array}{l}\text { DEMOGRAPHIC } \\
\text { S (PERSONAL } \\
\text { INFORMATION): } \\
\text { AGE: } 25-34\end{array}$ & $\begin{array}{r}\text { Sample } \\
(000) \\
\text { vert } \% \\
\text { horz } \% \\
\text { Index } \\
\text { Base }\end{array}$ & $\begin{array}{r}3,921 \\
36,435 \\
17.2 \% \\
100 \% \\
100 \\
17.2 \%\end{array}$ & $\begin{array}{r}241 \\
1,945 \\
24.8 \% \\
5.34 \% \\
144 \\
.92 \%\end{array}$ \\
\hline $\begin{array}{l}\text { DEMOGRAPHIC } \\
\text { S (PERSONAL } \\
\text { INFORMATION): } \\
\text { AGE: } 35-49\end{array}$ & $\begin{array}{r}\text { Sample } \\
(000) \\
\text { vert } \% \\
\text { horz } \% \\
\text { Index } \\
\text { Base }\end{array}$ & $\begin{array}{r}7,307 \\
61,745 \\
29.2 \% \\
100 \% \\
100 \\
29.2 \%\end{array}$ & $\begin{array}{r}364 \\
2,172 \\
27.7 \% \\
3.52 \% \\
95 \\
1.03 \%\end{array}$ \\
\hline $\begin{array}{l}\text { DEMOGRAPHIC } \\
\text { S (PERSONAL } \\
\text { INFORMATION): } \\
\text { AGE: } 50+\end{array}$ & $\begin{array}{r}\text { Sample } \\
(000) \\
\text { vert } \% \\
\text { horz } \% \\
\text { Index } \\
\text { Base }\end{array}$ & $\begin{array}{r}10,972 \\
89,379 \\
42.3 \% \\
100 \% \\
100 \\
42.3 \%\end{array}$ & $\begin{array}{r}325 \\
2,283 \\
29.2 \% \\
2.55 \% \\
69 \\
1.08 \%\end{array}$ \\
\hline
\end{tabular}


Table 2. Interpreting Simmons Choices3 Data

\begin{tabular}{|l|l|l|}
\hline KEY NUMBERS & DEFINITIONS & GUIDELINES \\
\hline Sample & $\begin{array}{l}\text { Actual number of respondents in survey who meet } \\
\text { criteria of both the row and column. }\end{array}$ & $\begin{array}{l}\text { 50+ very good } \\
30-50 \text { okay } \\
0-30 \text { not as reliable }\end{array}$ \\
\hline Index & $\begin{array}{l}\text { Indicates the likelihood, compared to the total } \\
\text { population, of meeting the specifications of both the } \\
\text { column and the row headings. The base number for } \\
\text { comparison is 100. }\end{array}$ & $\begin{array}{l}>120 \text { more likely } \\
<80 \text { less likely }\end{array}$ \\
\hline Projected (000) & $\begin{array}{l}\text { This number represents the total number of adults who } \\
\text { meet the specifications of both the row and the column. } \\
\text { The three 000s are added to the end of the number } \\
\text { shown. The numbers in this row are projections based } \\
\text { on the sample population of the survey. }\end{array}$ & \\
\hline
\end{tabular}

Table 3. Sample Question 2

\begin{tabular}{|l|l|l|}
\hline QUESTION & DEMOGRAPHIC VARIABLE & PRODUCT VARIABLE \\
\hline $\begin{array}{l}\text { Which age groups own } \\
\text { other brands of cell phones? }\end{array}$ & Age (Ranges 18-24, 25-34,35-49, 50+) & $\begin{array}{l}\text { Cell phone brand: Blackberry, } \\
\text { Sprint, LG, Motorola, Verizon }\end{array}$ \\
\hline
\end{tabular}


Figure 3. Owners of Selected Cellular Phones by Brand and Age Group

\begin{tabular}{|c|c|c|c|c|c|c|c|}
\hline & elements & total & $\begin{array}{l}\text { CELLULAR/IR } \\
\text { ELESS } \\
\text { PHONES: } \\
\text { CELLULARWIR } \\
\text { ELESS PHONES } \\
\text { - BRANDS } \\
\text { OWNED: } \\
\text { BLACKBERRY }\end{array}$ & $\begin{array}{l}\text { CELLULARWIR } \\
\text { ELESS } \\
\text { PHONES: } \\
\text { CELLULARWIR } \\
\text { ELESS PHONES } \\
\text { - BRANDS } \\
\text { OWNED: LG }\end{array}$ & $\begin{array}{l}\text { CELLULARWIR } \\
\text { ELESS } \\
\text { PHONES: } \\
\text { CELLULARWIR } \\
\text { ELESS PHONES } \\
\text { - BRANDS } \\
\text { OWNED: } \\
\text { MOTOROLA }\end{array}$ & $\begin{array}{l}\text { CELLULARWIR } \\
\text { ELESS } \\
\text { PHONES: } \\
\text { CELLULARWIR } \\
\text { ELESS PHONES } \\
\text { - BRANDS } \\
\text { OWNED: } \\
\text { SPRINT }\end{array}$ & $\begin{array}{l}\text { CELLULARWIR } \\
\text { ELESS } \\
\text { PHONES: } \\
\text { CELLULARWIR } \\
\text { ELESS PHONES } \\
\text { - BRANDS } \\
\text { OWNED: } \\
\text { VERIZON }\end{array}$ \\
\hline total & $\begin{array}{r}\text { Sample } \\
(000) \\
\text { vert } \% \\
\text { horz } \% \\
\text { Index } \\
\text { Base }\end{array}$ & $\begin{array}{r}24,617 \\
211,425 \\
100 \% \\
100 \% \\
100 \\
100 \%\end{array}$ & $\begin{array}{r}73 \\
648 \\
100 \% \\
.31 \% \\
100 \\
.31 \%\end{array}$ & $\begin{array}{r}983 \\
8,887 \\
100 \% \\
4.20 \% \\
100 \\
4.20 \%\end{array}$ & $\begin{array}{r}3,157 \\
28,083 \\
100 \% \\
13.3 \% \\
100 \\
13.3 \%\end{array}$ & $\begin{array}{r}1,072 \\
7,829 \\
100 \% \\
3.70 \% \\
100 \\
3.70 \%\end{array}$ & $\begin{array}{r}2,324 \\
18,617 \\
100 \% \\
8.81 \% \\
100 \\
8.81 \%\end{array}$ \\
\hline $\begin{array}{l}\text { DEMOGRAPHICS } \\
\text { (PERSONAL } \\
\text { INFORMATION): } \\
\text { AGE: } 18-24\end{array}$ & $\begin{array}{r}\text { Sample } \\
(000) \\
\text { vert\% } \\
\text { horz } \% \\
\text { Index } \\
\text { Base }\end{array}$ & $\begin{array}{r}2,417 \\
23,866 \\
11.3 \% \\
100 \% \\
100 \\
11.3 \%\end{array}$ & $\begin{array}{r}3 \\
39.0 \\
6.02 \% \\
.16 \% \\
53 \\
.02 \%\end{array}$ & $\begin{array}{r}111 \\
1,200 \\
13.5 \% \\
5.03 \% \\
120 \\
.57 \%\end{array}$ & $\begin{array}{r}307 \\
3,380 \\
12.0 \% \\
14.2 \% \\
107 \\
1.60 \%\end{array}$ & $\begin{array}{r}142 \\
1,428 \\
18.2 \% \\
5.98 \% \\
162 \\
.68 \%\end{array}$ & $\begin{array}{r}172 \\
1,865 \\
10.0 \% \\
7.81 \% \\
89 \\
.88 \%\end{array}$ \\
\hline $\begin{array}{l}\text { DEMOGRAPHICS } \\
\text { (PERSONAL } \\
\text { INFORMATION): } \\
\text { AGE: } 25-34\end{array}$ & $\begin{array}{r}\text { Sample } \\
(000) \\
\text { vert } \% \\
\text { horz } \% \\
\text { Index } \\
\text { Base }\end{array}$ & $\begin{array}{r}3,921 \\
36,435 \\
17.2 \% \\
100 \% \\
100 \\
17.2 \%\end{array}$ & $\begin{array}{r}7 \\
116 \\
17.8 \% \\
.32 \% \\
103 \\
.05 \%\end{array}$ & $\begin{array}{r}184 \\
2,049 \\
23.1 \% \\
5.62 \% \\
134 \\
.97 \%\end{array}$ & $\begin{array}{r}511 \\
4,991 \\
17.8 \% \\
13.7 \% \\
103 \\
2.36 \%\end{array}$ & $\begin{array}{r}241 \\
1,945 \\
24.8 \% \\
5.34 \% \\
144 \\
.92 \%\end{array}$ & $\begin{array}{r}322 \\
3,215 \\
17.3 \% \\
8.82 \% \\
100 \\
1.52 \%\end{array}$ \\
\hline $\begin{array}{l}\text { DEMOGRAPHICS } \\
\text { (PERSONAL } \\
\text { INFORMATION): } \\
\text { AGE: } 35-49\end{array}$ & $\begin{array}{r}\text { Sample } \\
(000) \\
\text { vert } \% \\
\text { horz\% } \\
\text { Index } \\
\text { Base }\end{array}$ & $\begin{array}{r}7,307 \\
61,745 \\
29.2 \% \\
100 \% \\
100 \\
29.2 \%\end{array}$ & $\begin{array}{r}37 \\
322 \\
49.7 \% \\
.52 \% \\
170 \\
.15 \%\end{array}$ & \begin{tabular}{r|}
337 \\
3,065 \\
$34.5 \%$ \\
$4.96 \%$ \\
118 \\
$1.45 \%$ \\
\end{tabular} & $\begin{array}{r}1,138 \\
9,504 \\
33.8 \% \\
15.4 \% \\
116 \\
4.50 \%\end{array}$ & $\begin{array}{r}364 \\
2,172 \\
27.7 \% \\
3.52 \% \\
95 \\
1.03 \%\end{array}$ & $\begin{array}{r}727 \\
5,401 \\
29.0 \% \\
8.75 \% \\
99 \\
2.55 \%\end{array}$ \\
\hline $\begin{array}{l}\text { DEMOGRAPHICS } \\
\text { (PERSONAL } \\
\text { INFORMATION): } \\
\text { AGE: } 50+\end{array}$ & $\begin{array}{r}\text { Sample } \\
(000) \\
\text { vert } \% \\
\text { horz } \% \\
\text { Index } \\
\text { Base }\end{array}$ & $\begin{array}{r}10,972 \\
89,379 \\
42.3 \% \\
100 \% \\
100 \\
42.3 \%\end{array}$ & $\begin{array}{r}26 \\
172 \\
26.5 \% \\
.19 \% \\
63 \\
.08 \%\end{array}$ & $\begin{array}{r}351 \\
2,574 \\
29.0 \% \\
2.88 \% \\
69 \\
1.22 \%\end{array}$ & $\begin{array}{r}1,201 \\
10,207 \\
36.3 \% \\
11.4 \% \\
86 \\
4.83 \%\end{array}$ & $\begin{array}{r}325 \\
2,283 \\
29.2 \% \\
2.55 \% \\
69 \\
1.08 \%\end{array}$ & $\begin{array}{r}1,103 \\
8,136 \\
43.7 \% \\
9.10 \% \\
103 \\
3.85 \%\end{array}$ \\
\hline
\end{tabular}


Table 4. Sample Questions Used in Librarian's Simmons Choices3 Class Presentation

\begin{tabular}{|l|l|l|}
\hline QUESTION & DEMOGRAPHIC VARIABLE & PRODUCT VARIABLE \\
\hline $\begin{array}{l}\text { Who are the people } \\
\text { buying HDTVs? }\end{array}$ & Gender: Male and Female & $\begin{array}{l}\text { TV Types: HDTV, Plasma, LCD, } \\
\text { and Giant Screen Proj. }\end{array}$ \\
\hline $\begin{array}{l}\text { Does education play a } \\
\text { role in TV selection? }\end{array}$ & $\begin{array}{l}\text { Education Level Attained: } \\
\text { High School 12 Years (Graduated), } \\
\text { College 4 Years (Graduate), } \\
\text { Attended Graduate School (Degree) }\end{array}$ & $\begin{array}{l}\text { TV Types: HDTV, Plasma, LCD, } \\
\text { and Giant Screen Proj. }\end{array}$ \\
\hline $\begin{array}{l}\text { What are the personal } \\
\text { financial opinions of } \\
\text { those purchasing } \\
\text { HDTVs? }\end{array}$ & $\begin{array}{l}\text { Lifestyle Statements on Personal } \\
\text { Finance (Agree a Lot): feel secure, } \\
\text { like others to think I'm a financial } \\
\text { success, don't like debt, very good } \\
\text { about managing money }\end{array}$ & $\begin{array}{l}\text { TV Types: HDTV, Plasma, LCD, } \\
\text { and Giant Screen Proj. }\end{array}$ \\
\hline $\begin{array}{l}\text { Where would you } \\
\text { advertise to reach HDTV } \\
\text { owners? }\end{array}$ & $\begin{array}{l}\text { Magazines Read in the Last 6 } \\
\text { months: Newsweek, Forbes, Maxim, } \\
\text { Entertainment Weekly, Reader's } \\
\text { Digest, People Weekly }\end{array}$ & $\begin{array}{l}\text { TV Types: HDTV, Plasma, LCD, } \\
\text { and Giant Screen Proj. }\end{array}$ \\
\hline $\begin{array}{l}\text { What other products do } \\
\text { HDTV users buy? }\end{array}$ & $\begin{array}{l}\text { Electronics owned: PDA, DVR, cell } \\
\text { phone }\end{array}$ & $\begin{array}{l}\text { TV Types: HDTV, Plasma, LCD, } \\
\text { and Giant Screen Proj. }\end{array}$ \\
\hline
\end{tabular}

Table 5. Simmons Choices3 Search Strategy

\begin{tabular}{|l|l|}
\hline QUESTIONS & EXAMPLES \\
\hline What is your product or brand? & computers, fast food, coffee, clothing \\
\hline What demographics do you want to know? & $\begin{array}{l}\text { age, gender, race, income, education, } \\
\text { marital status }\end{array}$ \\
\hline What psychographics do you want to know? & attitudes, values, beliefs \\
\hline $\begin{array}{l}\text { Where is the best place to advertise to reach my target } \\
\text { audience? }\end{array}$ & magazines, TV, radio \\
\hline What are products does my target audience buy? & cell phones, bottled water, designer clothing \\
\hline
\end{tabular}

